\title{
Adult Neurogenesis Is Necessary to Refine and Maintain Circuit Specificity
}

\author{
Diana M. Cummings, ${ }^{1}$ Jason S. Snyder, ${ }^{2}{ }^{-}$Michelle Brewer, ${ }^{2}$ Heather A. Cameron, ${ }^{2}$ and Leonardo Belluscio ${ }^{1}$ \\ ${ }^{1}$ Developmental Neural Plasticity Section, National Institute of Neurological Disorders and Stroke, National Institutes of Health, and ${ }^{2}$ Section on \\ Neuroplasticity, National Institute of Mental Health, National Institutes of Health, Bethesda, Maryland 20892
}

\begin{abstract}
The circuitry of the olfactory bulb contains a precise anatomical map that links isofunctional regions within each olfactory bulb. This intrabulbar map forms perinatally and undergoes activity-dependent refinement during the first postnatal weeks. Although this map retains its plasticity throughout adulthood, its organization is remarkably stable despite the addition of millions of new neurons to this circuit. Here we show that the continuous supply of new neuroblasts from the subventricular zone is necessary for both the restoration and maintenance of this precise central circuit. Using pharmacogenetic methods to conditionally ablate adult neurogenesis in transgenic mice, we find that the influx of neuroblasts is required for recovery of intrabulbar map precision after disruption due to sensory block. We further demonstrate that eliminating adult-born interneurons in naive animals leads to an expansion of tufted cell axons that is identical to the changes caused by sensory block, thus revealing an essential role for new neurons in circuit maintenance under baseline conditions. These findings show, for the first time, that inhibiting adult neurogenesis alters the circuitry of projection neurons in brain regions that receive new interneurons and points to a critical role for adult-born neurons in stabilizing a brain circuit that exhibits high levels of plasticity.
\end{abstract}

Key words: interneuron; intrabulbar map; neurogenesis; olfactory deprivation; rostral migratory stream; subventricular zone

\section{Introduction}

In mammals, olfactory sensory neurons (OSNs) each express one of $>1300$ possible odorant receptors (ORs), and OSNs that express the same OR project axons that typically converge on two glomeruli within each olfactory bulb (OB). Pairs of glomeruli define isofunctional odor columns that extend from the glomeruli at the surface of the OB through the deeper layers that include projection neurons as well as interneurons. Whereas mitral cells are the primary output neurons of the bulb, tufted cells are output neurons that also project locally to connect the medial and lateral halves of each OB (Schoenfeld et al., 1985). Each tufted cell extends a single dendrite into the glomerulus above it and an axon that specifically targets GABAergic interneurons located beneath the "partner" glomerulus on the opposite side of the OB, thus linking isofunctional odor columns in an intrabulbar map (Liu and Shipley, 1994; Belluscio et al., 2002; Lodovichi et al., 2003). At birth, intrabulbar projections are broad but then refine

\footnotetext{
Received June 8, 2014; revised Aug. 26, 2014; accepted Sept. 2, 2014

Author contributions: D.M.C., H.A.C., and L.B. designed research; D.M.C. performed research; J.S.S., M.B., and H.A.C. contributed unpublished reagents/analytic tools; D.M.C. and L.B. analyzed data;D.M.C.,H.A.C., and L.B. wrote the paper.

This work was supported by the Intramural Research Program of the National Institutes of Health, National Institute of Neurological Disorders and Stroke, and the National Institute of Mental Health.

The authors declare no competing financial interests.

Correspondence should be addressed to Dr. Leonardo Belluscio, Developmental Neural Plasticity Section, National Institute of Neurological Disorders and Stroke, Porter Neuroscience Research Center, Building 35, Room 3E-410, 35 Convent Drive, MSC 3703, Bethesda, MD 20892-3703. E-mail: belluscl@ninds.nih.gov.

J.S. Snyder's present address: University of British Columbia, Department of Psychology, Vancouver, British Columbia V6T 1Z4, Canada.

DOI:10.1523/JNEUROSCI.2463-14.2014

Copyright $\odot 2014$ the authors $\quad 0270-6474 / 14 / 3413801-10 \$ 15.00 / 0$
}

to their mature specificity, approximately the width of a glomerulus, by 7 weeks of age. This axonal refinement is accelerated by enhanced olfactory input and prevented by olfactory deprivation (Marks et al., 2006). Plasticity in the specificity of these connections is maintained throughout life such that axons broaden following sensory deprivation but refine once again when afferent activity is restored (Cummings and Belluscio, 2010).

One striking observation is that the precision of intrabulbar circuitry is preserved despite the continuous replacement of granule cells, the major recipients of tufted cell intrabulbar connections. Granule cells include several chemically defined subpopulations (Imamura et al., 2006; Parrish-Aungst et al., 2007; Batista-Brito et al., 2008; Yoshihara et al., 2012), which are generated in the subventricular zone (SVZ) as doublecortin (DCX)positive neuronal precursors and migrate to the $\mathrm{OB}$ via the rostral migratory stream (RMS) (see Fig. $1 A$ ) (Lois and Alvarez-Buylla, 1994). In the OB, they move radially and extend dendrites through the apical layers to become functionally integrated into circuits (Belluzzi et al., 2003; Carleton et al., 2003; Lepousez et al., 2013). Studies have shown that new granule cells receive synaptic input within a few days of entering the OB (Panzanelli et al., 2009; Katagiri et al., 2011) and that their survival is activity dependent (Yamaguchi and Mori, 2005), suggesting that they could play a role in intrabulbar circuit plasticity.

A variety of approaches have been used to kill SVZ progenitor cells in an effort to uncover the purpose of this continuous infiltration of adult-generated neurons (Imayoshi et al., 2008; Breton-Provencher et al., 2009). Although the loss of cells that would normally become synaptically integrated must alter the circuits that would normally have included them, no changes in 
other neurons have been identified. Thus, the potential impact on the specificity of OB circuitry following SVZ stem cell ablation is unknown. In this study, we used anterograde tracers to examine the terminal fields of tufted cells in normal mice and in transgenic mice specifically lacking adult neurogenesis to reveal clear anatomical changes in the specificity of intrabulbar map circuitry.

\section{Materials and Methods}

Transgenic mice and valganciclovir (vGCV) administration. All procedures followed the Institute of Laboratory Research guidelines and were approved by the Animal Care and Use Committee of the National Institute of Neurological Disorders and Stroke. GfapTK mice have been described previously (Snyder et al., 2011). NestinTK transgenic mice were generated using a construct containing the nestin promoter region (Panchision et al., 2001) upstream from the HSV-TK gene. Both TK lines were crossed onto a GAD65-GFP background, and experimental male mice were given vGCV at the appropriate dose at 7-10 weeks of age for 6 weeks. To investigate glomerular targeting following stem cell ablation, GfapTK mice were crossed with either P2-IRES-taulac $Z$ or M71-IRES-taulacZ lines that contain OSNs, which express IRES-taulac $Z$ under the promoters for the P2 or M71 odorant receptors, respectively (Mombaerts et al., 1996; Royal and Key, 1999; Vassalli et al., 2002). Offspring were given vGCV for 6 weeks starting at 7 weeks of age, and tissue was collected and processed for $\beta$-galactosidase immunohistochemistry as previously described (Cummings and Belluscio, 2010). To assess neurogenesis in the GfapTK and NestinTK lines, mice were killed $2 \mathrm{~h}$ after a single injection of BrdU (50 mg/kg). BrdU and all other immunohistochemical procedures were conducted as previously described (Cummings et al., 1997; Cummings and Belluscio, 2010) using antibodies at concentrations listed in Table 1 . Tissue sections were coverslipped using fluorescent mounting media containing either DAPI or propidium iodide for Nissl staining.

Reversible naris closure and neural tracer injections. Reversible naris closure was performed in 7- to 10-week-old GfapTK and NestinTK male mice as described previously (Cummings and Belluscio, 2010). Discrete, iontophoretic injections of $10 \%$ dextran tetramethylrhodamine (TMR) were targeted to the dorsal surface of the $\mathrm{OB}$ as described previously (Cummings and Belluscio, 2010) to visualize intrabulbar projections in experimental and control TK mice.

Image acquisition, quantification, and analysis. Immunostaining and images of TMR injection and projection sites were collected using a Zeiss LSM 510 laser scanning confocal microscope. Projection sites were reconstructed in 3D using LSM software, and diameters of projection and corresponding injection sites were expressed as ratios, averaged, and reported as \pm SEM. Quantification of DCX-immunoreactive process densities was performed using Volocity Image Analysis Software (PerkinElmer). Images were normalized (0-255), and DCX-containing processes were quantified based on size (minimal size: $1 \mu \mathrm{m}^{2}$ ) and intensity thresholding (2 SD above the mean). Threshold levels were kept constant across all measured sections, and DCX-expressing processes were quantified along and divided by the length of the internal plexiform layer (IPL) to generate density values. Projection to injection ratios and
Table 1. Primary antibodies used

\begin{tabular}{llll}
\hline Antigen & Species & Source & Dilution \\
\hline$\beta$-Galactosidase ( $\beta$-gal) & Mouse & Promega & $1: 1000$ \\
BrdU & Rat & Accurate Scientific & $1: 400$ \\
Calretinin & Goat & R\&D Systems & $1: 1000$ \\
Calretinin & Rabbit & Chemicon & $1: 2500$ \\
Doublecortin & Goat & Santa Cruz Biotechnology & $1: 400$ \\
GFAP & Rabbit & Invitrogen & $1: 500$ \\
Tetramethylrhodamine & Rabbit & Invitrogen & $1: 5000$ \\
VGLUT2 & Guinea pig & Millipore & $1: 1000$ \\
\hline
\end{tabular}
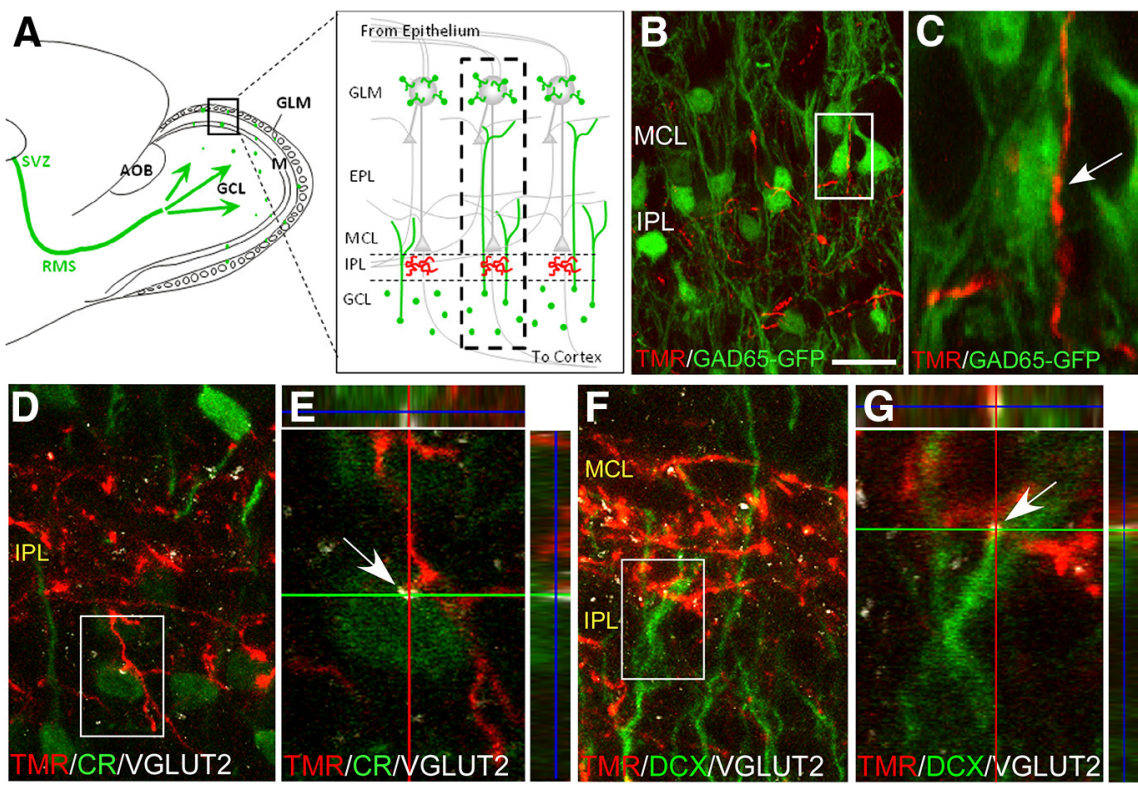

Figure 1. Intrabulbar axons contact preexisting and incoming GABAergic interneurons. $A$, Schematic illustrating the migration tracing that labels intrabulbar axons in combination with GAD65-GFP expression indicates that intrabulbar projections target GAD65-positive GABAergic interneurons in the region of the IPL and MCL. $\boldsymbol{C}$, Higher magnification of boxed region in $\boldsymbol{B}$ shows are localized to VGLUT2-immunopositive puncta (white arrows), suggesting that intrabulbar axons target preexisting $(\boldsymbol{D}, \boldsymbol{E})$ and new $(\boldsymbol{F}, \boldsymbol{G})$ interneurons within the IPL. Scale bars: $\boldsymbol{B}, \boldsymbol{C}, 20 \mu \mathrm{m} ; \boldsymbol{D}, \boldsymbol{F}, 10 \mu \mathrm{m} ; \boldsymbol{E}, \boldsymbol{G}, 5 \mu \mathrm{m}$.

process densities were analyzed with either $t$ tests or one-way ANOVAs followed by post hoc comparisons using the Holm-Sidak method. Significance was set at $p<0.05$.

\section{Results}

\section{Intrabulbar axons target both mature and newly generated} granule cells

We first asked whether intrabulbar axons, which terminate on GABAergic cells within the IPL (Liu and Shipley, 1994), target both newly generated as well as mature granule cells in this layer. We used discrete injections of dextran TMR to label tufted cells in GAD65-GFP mice to visualize intrabulbar projection axon tufts. High-magnification confocal images showed that TMRcontaining intrabulbar axons closely appose GAD65-GFP positive $(+)$ interneurons in the IPL making varicosities consistent with synaptic boutons (Fig. $1 B, C$ ), as previously observed with biocytin and electron microscopy (Liu and Shipley, 1994). We combined tufted cell labeling using TMR injections with dual 

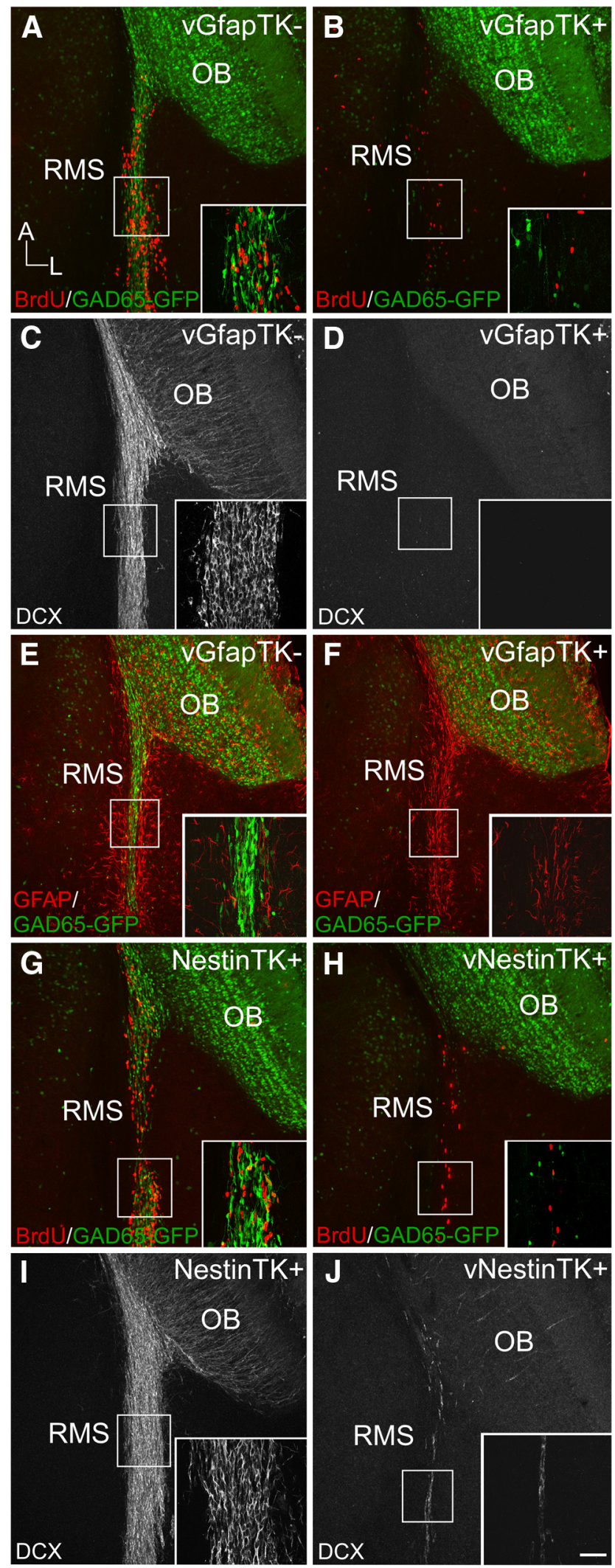

Figure 2. The influx of new neurons is completely eliminated in GfapTK mice and largely inhibited in NestinTK mice. After 6 weeks of $\mathrm{VGCV}$ treatment, proliferating BrdU ${ }^{+}$profiles (red) were visible among GAD65-GFP ${ }^{+}$neuroblasts (green) in $\mathrm{GfapTK}^{-}$mice $(\boldsymbol{A})$, but few BrdU ${ }^{+}$or $\mathrm{GAD65} \mathrm{GFP}^{+}$cells remained in GfapTK ${ }^{+}$mice $(\boldsymbol{B})$. This lack of proliferation within the RMS corresponded to an absence of $D C X$-immunoreactive immature neurons along this pathway in treated $\mathrm{GfapTK}^{+}$mice $(\boldsymbol{D})$ in contrast to large numbers of $D C X$-expressing neural progenitors immunohistochemistry for a glutamatergic synapse marker, vesicular glutamate transporter 2 (VGLUT2), and markers for either mature or immature neurons. Results from this triple labeling approach indicated that intrabulbar axons contact both mature (calretinin-positive) and immature (doublecortin-positive) neurons (Fig. $1 D, F$ ) in the IPL. Confocal images and orthogonal analyses further suggested that TMR-containing axons come into contact with mature granule cells as well as incoming, new neurons and that VGLUT2-immunoreactive puncta were localized to these juxtapositions (Fig. 1E,G). These findings suggest that tufted cells may synapse onto adult-born granule cells.

\section{Adult-born stem cells from the SVZ can be eliminated in} GfapTK $^{+}$and NestinTK ${ }^{+}$mice

Because tufted cell axons associate with immature neurons, we tested the hypothesis that newly generated granule cells are critical for intrabulbar map plasticity by altering adult neurogenesis. Treatment of GfapTK ${ }^{+}$mice with the antiviral drug vGCV has previously been shown to totally eliminate neurogenesis in the dentate gyrus while sparing postmitotic GFAP-positive astroglia (Snyder et al., 2011). We evaluated the extent of SVZ stem cell ablation by examining the RMS of GfapTK mice crossed into a GAD65-GFP background to allow for clear identification of GABAergic neural precursors (Fig. $2 A, B$ ). After 6 weeks of vGCV treatment, we labeled dividing cells with BrdU and found few $\mathrm{GAD} 5-\mathrm{GFP}^{+}$cells or BrdU-positive profiles in the RMS of Gfa$\mathrm{pTK}^{+}$mice (Fig. $2 B$ ) compared with $\mathrm{GfapTK}^{-}$controls (Fig. $2 A$ ). This loss of $\mathrm{OB}$ granule cell genesis was further evident from the absence of young, DCX-expressing neurons in both the RMS and $\mathrm{OB}$ of vGCV-treated GfapTK ${ }^{+}$mice (Fig. $2 C, D$ ). The complete ablation of the RMS in $\mathrm{GfapTK}^{+}$mice is consistent with the expression of GFAP in SVZ stem cells (Doetsch et al., 1999; Garcia et al., 2004). Interestingly, GFAP-expressing astrocytes along the RMS, which are thought to facilitate neuroblast migration (Lois et al., 1996; Peretto et al., 1997), also remained intact after vGCV treatment, indicating that the presence of stem cells migrating along this route is not necessary to maintain the glial tube network (Fig. $2 E, F$ ).

We created an additional transgenic mouse strain expressing TK under the control of the nestin promoter to ensure that experimental results could be attributed to SVZ stem cell depletion rather than to a specific transgene or strain (Panchision et al., 2001). As in the GfapTK mice, we assessed the effectiveness of ablating SVZ-derived neuroblasts in NestinTK mice by crossing them to GAD65-GFP mice and used BrdU to examine cell proliferation along the RMS. After 6 weeks of vGCV treatment, NestinTK ${ }^{+}$mice showed an almost complete absence of GAD65$\mathrm{GFP}^{+}$neuroblasts and very few BrdU ${ }^{+}$cells (Fig. $2 H$ ). In contrast, many BrdU ${ }^{+}$and GAD65-GFP ${ }^{+}$cells were present in the RMS of NestinTK ${ }^{+}$control mice that did not receive vGCV (Fig. $2 G)$. Analysis with DCX immunohistochemistry revealed similar results with few DCX-immunoreactive cells remaining in the

$\leftarrow$

in GfapTK ${ }^{-}$controls $(\boldsymbol{C}) \boldsymbol{E}, \boldsymbol{F}$, Immunostaining for GFAP (red) revealed that scaffold-forming astrocytes within the RMS persisted in GFAP-TK ${ }^{+}$mice given vGCV $(\boldsymbol{F})$ despite the absence of migrating GABAergic stem cells (green). Many BrdU ${ }^{+} /{\mathrm{GAD} 65-\mathrm{GFP}^{+}}^{+}$cells were also present within the RMS of untreated (no vGCV) NestinTK control mice (G); however, all GAD65-GFP ${ }^{+}$ cells and most BrdU ${ }^{+}$cells in treated NestinTK mice were eliminated $(\boldsymbol{H})$. DCX immunostaining results supported this substantial, but incomplete, ablation because many incoming $D C X^{+}$ immature neurons were visible in the RMS of untreated NestinTK ${ }^{+}$controls $(I)$, whereas few $D C X^{+}$cells remained in NestinTK ${ }^{+}$mice treated with vGCV (J). $A-J$, Boxed areas along the RMS are shown in higher-magnification insets. Scale bars: $A-J, 100 \mu \mathrm{m}$; insets, $20 \mu \mathrm{m}$. 
RMS of vGCV-treated NestinTK ${ }^{+}$mice, whereas many incoming DCX-positive immature neurons were present in the RMS of untreated NestinTK ${ }^{+}$controls (Fig. $2 I, J$ ).

\section{Ablation of adult-born neurons does not disrupt OSN proliferation or glomerular targeting}

Initially, we examined stem cell proliferation in the olfactory epithelia of GfapTK and NestinTK mice to ensure that vGCV treatment selectively ablated SVZ stem cells without affecting populations of OSNs. After 6 weeks of vGCV treatment (Fig. 3A), short-survival BrdU experiments revealed that the olfactory epithelium in vGCV-treated $\mathrm{GfapTK}^{+}$and NestinTK ${ }^{+}$mice contained numerous dividing, BrdU-positive, OSNs (Fig. 3C,E) and were indistinguishable from the epithelia in vGCV-treated GfapTK $^{-}$and untreated NestinTK ${ }^{+}$controls (Fig. $3 B, D$ ). These results indicate that OSNs, unlike granule cells, remain intact in this pharmacogenetic model and suggest that primary OSNs derive from stem cells that do not express GFAP or Nestin.

Because alterations in glomerular map formation and maintenance may influence downstream circuitry, we also investigated the specificity of glomerular targeting in our ablation model by examining the offspring of GfapTK mice crossed to either M71-ETL or P2-ETL lines. This approach allowed us to visualize axonal convergence into representative dorsal (M71) or ventral (P2) glomeruli by treating GfapTK/M71-ETL or GfapTK/P2-ETL mice with vGCV for 6 weeks and processing OB tissue section for $\beta$-galactosidase immunohistochemistry. Results from these experiments suggested no discernible difference in OSN axonal convergence and glomerular targeting for either the M71 (Fig. 3F, G) or P2 (Fig. 3 H, I) glomeruli after adult-born stem cell ablation. This observation suggests that the glomerular map is not altered by vGCV treatment or the lack of new SVZ-derived neurons.

\section{Adult-born neurons are ablated without altering gross olfactory bulb morphology}

Since other studies have reported structural disruptions within the olfactory bulb following SVZ stem cell ablation (Imayoshi et al., 2008), we conducted detailed histological analyses of the subependymal layer (SEL) within the center of the OB, which is the entry point for RMS neuroblasts. We examined GAD65-GFP expression in combination with Nissl staining and DCX immunohistochemistry to address the possibility that stem cell ablation in vGCV-treated GfapTK or NestinTK mice produces changes in gross olfactory bulb morphology. Images of horizontal sections through the center of the SEL in control mice (vGCV-treated GfapTK $^{-}$and untreated NestinTK ${ }^{+}$) revealed dense populations of GAD65-GFP-expressing cells within this region (Fig. $4 A, C)$. This cluster of incoming cells was also visible with Nissl staining and corresponded to DCX-immunopositive cell bodies that appeared to be entering the $\mathrm{OB}$ and extending processes radially into more superficial layers (Fig. $4 A, C$ ). Six weeks of vGCV treatment in $\mathrm{GfapTK}^{+}$or NestinTK ${ }^{+}$mice resulted in a dearth of GAD65-GFP-expressing cells in the SEL that corresponded to an absence of dense clusters of Nissl-stained cells in this region (Fig. $4 B, D$ ). However, Nissl-stained cells were sparse but not absent from the SEL, and there was no evidence of holes or malformations in this or any other area of the OB (Fig. $4 B, D$ ). As observed in sections through the RMS, DCX immunostaining was completely absent in sections through the SEL of treated GfapTK $^{+}$mice (Fig. $4 B$ ) and substantially reduced in treated NestinTK ${ }^{+}$mice (Fig. 4D).

We sought to further characterize potential changes in the cellular environment of the $\mathrm{OB}$ that directly results from SVZ
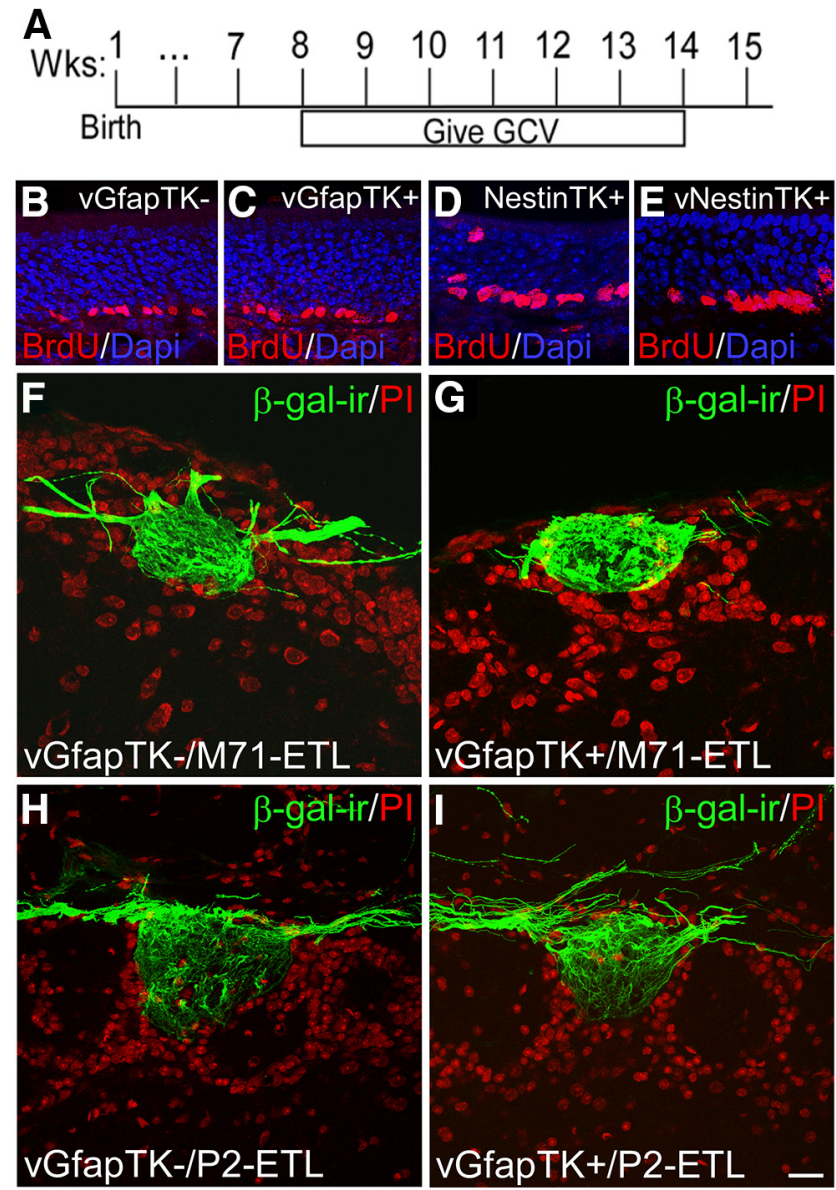

Figure 3. Adult-born stem cell ablation does not alter OSN proliferation in the olfactory epithelium or glomerular targeting. After 6 weeks of $v G C V$ treatment $(\boldsymbol{A})$, proliferation within the OSN stem cell population appeared unaffected in GfapTK and NestinTK models, as evidenced by BrdU staining (red) within the olfactory epithelia of treated GfapTK ${ }^{+}$and NestinTK ${ }^{+}$mice ( $\boldsymbol{C}$ and $\boldsymbol{E}$, respectively), which did not differ from treated $\mathrm{GfapTK}^{-}$and untreated NestinTK ${ }^{+}$ controls ( $\boldsymbol{B}$ and $\boldsymbol{D}$, respectively). Immunohistochemistry for $\beta$-gal in OB sections from $\mathrm{VGCV}$ treated GfapTK/M71-IRES-taulacZ and GfapTK/P2-IRES-taulacZ mice was conducted to assess potential effects of adult stem cell ablation on the glomerular map $(\boldsymbol{F}-\boldsymbol{I})$. As illustrated by confocal images of $\beta$-gal-ir in representative dorsal M71 $(\boldsymbol{F}, \boldsymbol{G})$ and ventromedial P2 $(\boldsymbol{H}, \boldsymbol{I})$ glomeruli, OSN axonal convergence and glomerular targeting did not differ in control GfapTK $^{-}$/M71-IRES-taulacZ $(\boldsymbol{F})$ and GfapTK ${ }^{-}$/P2-IRES-taulacZ $(\boldsymbol{H})$ control mice compared with GfapTK ${ }^{+} /$M71-IRES-taulacZ (G) and GfapTK ${ }^{-} /$P2-IRES-taulacZ (I) that experienced stem cell ablation for 6 weeks. PI, Propidium iodide. Scale bar, $20 \mu \mathrm{m}$.

stem cell loss or reduction after vGCV treatment. Because intrabulbar axons terminate within the IPL and associate with DCXpositive cells and processes in this layer, we quantified the density of apical processes that extend radially through the IPL (Fig. $4 E-$ $H)$. Quantification of DCX-expressing process densities in the OB of control and treated GfapTK and NestinTK mice further confirmed the complete ablation (100\% reduction) of incoming interneurons in the GfapTK model $(t=55.56, p<0.001)$ and a considerable, although less complete, ablation ( $89 \%$ reduction) in NestinTK mice $(t=29.88, p<0.001$; Fig. $4 E-I)$. In addition, we quantified the density of GAD65-GFP ${ }^{+}$cells in the granule cell layer and mitral cell layer of control and experimental GfapTK and NestinTK mice to determine whether the absence of SVZ stem cells alters the overall density of this population of GABAergic interneurons. Analyses of GAD65-GFP ${ }^{+}$cell densities revealed no differences between control and experimental GfapTK or NestinTK mice (Fig. 4J-N). Together, these results indicate that vGCV treatment of $\mathrm{GfapTK}^{+}$and NestinTK ${ }^{+}$mice 


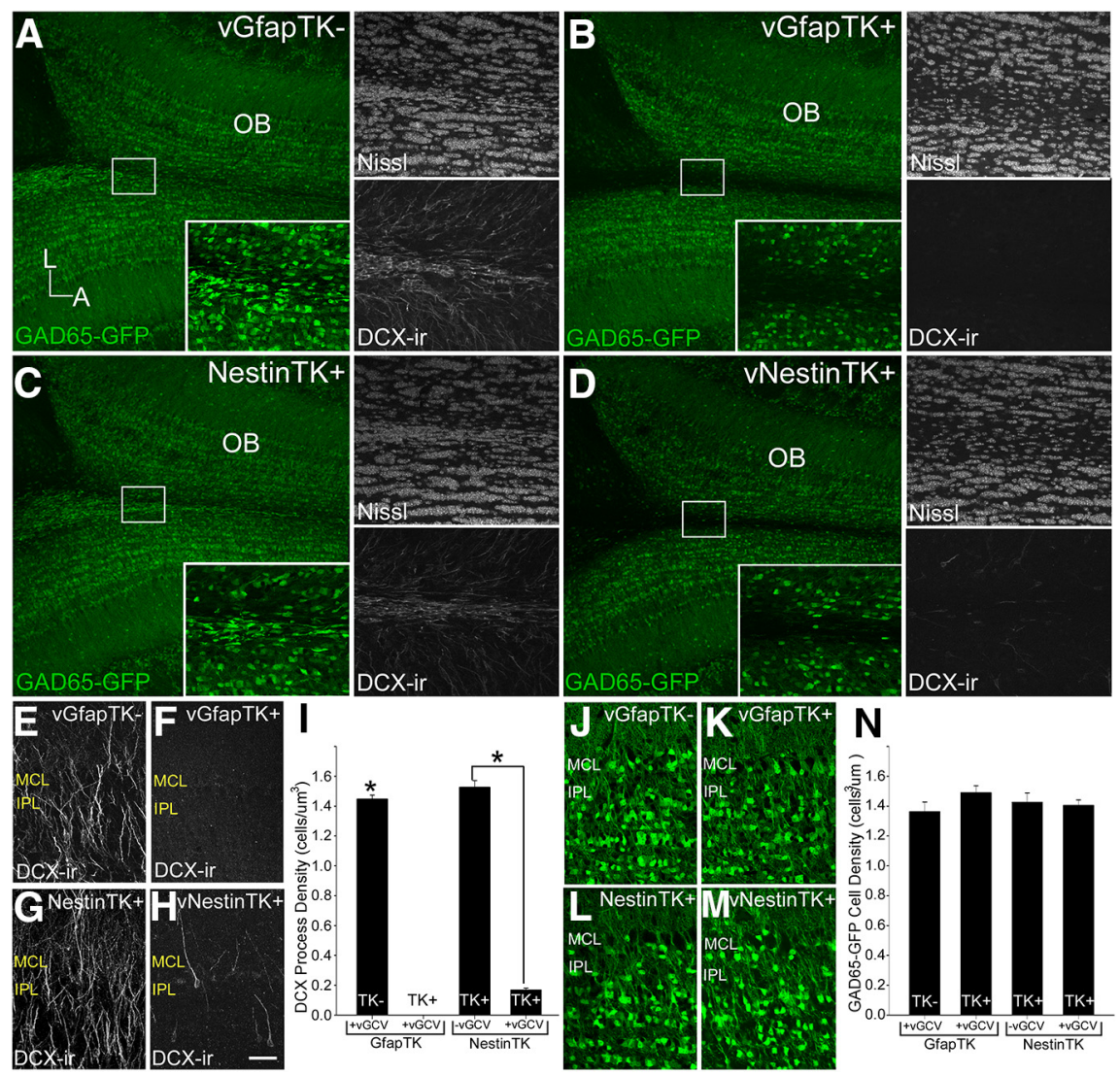

Figure 4. Ablation of adult-born neuroblasts does not cause morphological anomalies in OB tissue. Incoming GAD65-GFP-containing neuroblasts were visible in the SEL of treated $\mathrm{GfapTK}^{-}(\boldsymbol{A})$ and untreated NestinTK ${ }^{-}(\boldsymbol{C})$ controls. These populations of GAD65-GFP ${ }^{+}$cells corresponded to dense clusters of Niss--stained cells that were immunoreactive for DCX (A, $C$. After 6 weeks of treatment with vGCV in $\mathrm{GfapTK}^{+}$and NestinTK ${ }^{+}$mice, GAD65-GFP ${ }^{+}$cells were absent from the SEL $(\boldsymbol{B}, \boldsymbol{D})$. Nissl-stained profiles, however, were present in this region, though less dense; and the basic organization of the $O B$ did not contain any structural abnormalities. DCX-immunopositive cells were either completely absent or very sparse in the SEL of treated GfapTK ${ }^{+}$or NestinTK ${ }^{+}$mice, respectively $(\boldsymbol{B}, \boldsymbol{D})$. Quantification of $D C X$-containing processes extending radially into the $O B$ further confirmed this observation in the GfapTK ( $t=55.56,{ }^{*} p<0.001$ ) and NestinTK ( $t=29.88, p<0.001)$ models $(\boldsymbol{E}-\boldsymbol{I})$. However, the lack of SVZ stem cells did not change the densities of the general population of GAD65-GFP-containing cells in GfapTK and NestinTK mice $(J-N)$. Scale bars: $A-D, 200 \mu \mathrm{m}$; insets, $50 \mu \mathrm{m}$.

decreases $\mathrm{DCX}^{+}$cells and processes without impacting the overall density of the general population of GABAergic granule cells. Unlike findings using other stem cell ablation models (Imayoshi et al., 2008), vGCV treatment for 6 weeks in $\mathrm{GfapTK}^{+}$and $\mathrm{NestinTK}^{+}$mice did not cause any gross morphological changes in the olfactory system.

\section{Restoration of intrabulbar refinement requires adult-born neurons}

Using GfapTK mice, we tested whether adult-generated interneurons are necessary for restoring the precision of intrabulbar projections following a disruption in connectivity that results from sensory deprivation. Intrabulbar projection specificity was assessed using discrete injections of TMR into the glomerular layer, as described previously (Cummings and Belluscio, 2010) (Fig. 5A). Naive GfapTK mice and wild-type littermates experienced naris closure from 7 to 10 weeks of age followed by a 6 week recovery period when all mice were given vGCV. Two additional groups of mice, naris occluded and unmanipulated controls, were also examined at 10 weeks of age, before the recovery period (Fig. 5B). We observed significant broadening of intrabulbar projections in both $\mathrm{GfapTK}^{+}$and wild-type $\left(\mathrm{GfapTK}^{-}\right)$mice after 3 weeks of activity deprivation compared with unblocked control mice (average projection to injection ratios $=1: 3.43 \pm 0.07$ and
1:1.38 \pm 0.05 for blocked and unblocked, respectively; Fig. $5 C, D, G$ ), in agreement with results from other transgenic and wild-type lines (Marks et al., 2006). Following a recovery period when the naris block was removed to restore sensory activity, intrabulbar projections in Gfa$\mathrm{pTK}^{-}$mice with normal levels of adult neurogenesis returned to control levels of specificity (average ratio $=1: 1.35 \pm 0.02$; Fig. $5 E, G)$. However, when neurogenesis was prevented during this period, intrabulbar projections were as broad as those in naris-occluded controls (average ratio $=$ $1: 3.69 \pm 0.15$; Fig. $5 F, G$ ). Further analysis revealed significant differences across GfapTK treatment groups (one-way ANOVA, $\left.F_{(3,12)}=208.11 ; p<0.001\right)$, and comparing intrabulbar projection with injection ratios showed that mice lacking neurogenesis during recovery had significantly broader axonal projections compared with mice with normal neurogenesis (Holm-Sidak method, GfapTK: $t=18.74$; $p<0.005)$. These results indicate that inhibiting neurogenesis led to a complete lack of refinement of intrabulbar axonal precision following disruption due to sensory deprivation.

$\mathrm{NestinTK}^{+}$mice also showed significant broadening of intrabulbar projections in response to activity deprivation via naris closure (average projection to injection ratios $=1: 3.51 \pm 0.20$ and $1: 1.36 \pm 0.12$ for NestinTK ${ }^{+}$blocked and unblocked mice, respectively; Fig. $6 A-$ $C, F)$, similar to results from GfapTK and wild-type mice (Cummings and Belluscio, 2010). Importantly, vGCV-treated $\mathrm{NestinTK}^{+}$mice showed the same lack of projection refinement following reinstatement of activity that was seen in GfapTK mice (average ratios $=1: 3.55 \pm 0.09$ and 1:1.28 \pm 0.15 for vGCV treated and untreated NestinTK ${ }^{+}$mice, respectively; Fig. $6 D-F$ ), despite the incomplete loss of new neurons. Analysis of these data demonstrated significant differences across NestinTK treatment groups (one-way ANOVA, $F_{(3,12)}=77.07 ; p<0.001$ ), and post hoc tests (Holm-Sidak method) revealed significantly broader axonal projections in mice with inhibited neurogenesis during recovery compared with those with normal neurogenesis during recovery $(t=11.02 ; p<0.005)$. The similar findings in both GfapTK and NestinTK experiments, which used two different promoters and varied either genotype or vGCV treatment, argue against either nonspecific drug or transgene insertion effects. Together, these results indicate that afferent activity is not sufficient to restore intrabulbar map specificity in the absence of adult-born interneurons.

\section{Adult-born stem cells are necessary for intrabulbar map maintenance}

Because new neurons play an important role in restoring intrabulbar circuit specificity, we next asked whether they affect intrabulbar projections under control conditions, without altering activity levels or disrupting the preexisting granule cells. Naive, 

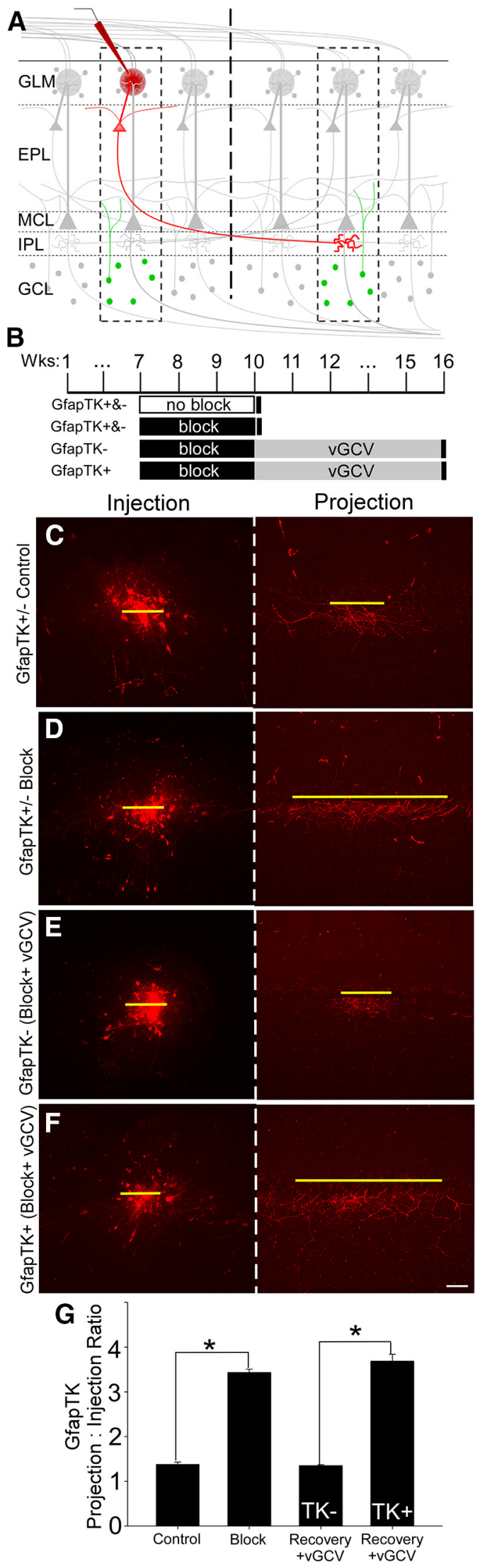

Figure 5. Adult neurogenesis is necessary for the restoration of intrabulbar specificity after activity deprivation. $\boldsymbol{A}$, Schematic illustrates a discrete iontophoretic tracer injection of TMR that labels tufted cells within an olfactory column and allows for visualization of associated axonal projection tufts within the IPL of the isofunctional column on the opposite side of the OB. $\boldsymbol{B}$, adult GfapTK, and NestinTK mice were given vGCV for 6 weeks to ablate neurogenesis, whereas control mice either did not express the transgene ( $\mathrm{GfapTK}^{-}$, experimental controls) or were not given vGCV (NestinTK ${ }^{+}$, experimental controls) (Fig. 7A). Control mice lacking GfapTK ${ }^{-}$expression showed discrete intrabulbar projections (average projection to injection ratio $=$ $1: 1.25 \pm 0.03$; Fig. $7 B$ ), whereas $\mathrm{GfapTK}^{+}$mice that received vGCV exhibited broad projection tufts (average ratio $=1: 3.50 \pm$ 0.20 ; Fig. $7 C$ ). Intrabulbar projections were also refined in $\mathrm{NestinTK}^{+}$control mice that were not treated with vGCV (average ratio $=1: 1.31 \pm 0.10$; Fig. $7 D$ ); however, projections of treated $\mathrm{NestinTK}^{+}$mice were expanded (average ratio = 1:2.46 \pm 0.16; Fig. 7E). Data analysis across all GfapTK and NestinTK groups revealed significant differences in intrabulbar projection sizes (one-way ANOVA; $F_{(3,16)}=49.64 ; p<0.001$ ). Post hoc comparisons (Holm-Sadik method) further revealed significant differences in the projection sizes of treated GfapTK ${ }^{-}$ versus $\mathrm{GfapTK}^{+}$mice $(t=10.02 ; p<0.005)$ as well as those of untreated and treated NestinTK mice $(t=5.22 ; p<0.005)$ (Fig. $7 F)$. Interestingly, intrabulbar projection sizes of treated NestinTK mice were significantly more expanded than those of controls, but not as broad as the projections of treated $\mathrm{GfapTK}^{+}$ mice $(t=4.95, p<0.01)$. These results indicate that simply preventing the influx of neuroblasts for 6 weeks is sufficient to induce a significant anatomical change in the intrabulbar circuitry. The observed broadening of projections in the animals lacking adult neurogenesis was virtually identical to that seen after sensory deprivation, further demonstrating that the integration of new interneurons is critical for maintaining intrabulbar circuit precision, even with normal sensory experience and a normal complement of mature granule cells.

\section{Discussion}

Our results illustrate that adult-born, SVZ-derived stem cells are critical for both the restoration and maintenance of circuitry that links isofunctional regions within a carefully orchestrated intrabulbar map. When intrabulbar connections were disrupted by sensory deprivation, we found that neurogenesis was necessary to restore baseline levels of tufted cell axonal precision. Naris occlusion causes a substantial loss of granule cells (Fiske and Brunjes, 2001; Yamaguchi and Mori, 2005) that is at least partially restored by neuronal replacement when activity levels are reinstated (Cummings et al., 1997). Granule cell turnover appears to be functionally linked to the recovery of tufted cell projection specificity because reinstatement of activity alone did not lead to the return of intrabulbar axonal precision in mice lacking adult neurogenesis. This link supports the possibility that intrabulbar axons lose synaptic connections with dying granule cells, expand to

\footnotetext{
$\longleftarrow$

Timelines of experimental design show that transgenic $(+)$, wild-type $(-)$ littermate, or mixed genotype mice experienced naris block followed by a recovery period after removal of the block when some mice were given vGCV to eliminate adult neurogenesis. Intrabulbar projections were visualized with tracer injections conducted $18-20 \mathrm{~h}$ before death. At 10 weeks of age, untreated GfapTK control mice exhibited control levels of intrabulbar projection specificity (C). However, naris closure from 7 to 10 weeks resulted in a significant broadening of these projections $(\boldsymbol{D})$. When GfapTK - mice experienced naris block followed by normal neurogenesis during recovery, intrabulbar axon tufts appeared refined as illustrated in representative images of injection and projection sites $(\boldsymbol{E})$. However, inhibition of neurogenesis during recovery from sensory deprivation resulted in broad intrabulbar axonal projections $(\boldsymbol{F}) . \mathbf{G}$, Graph of average projection to injection ratios for GfapTK groups (mean \pm SEM). ${ }^{*} p<0.001$ (one-way ANOVA). Scale bar, $50 \mu \mathrm{m}$.
} 
A
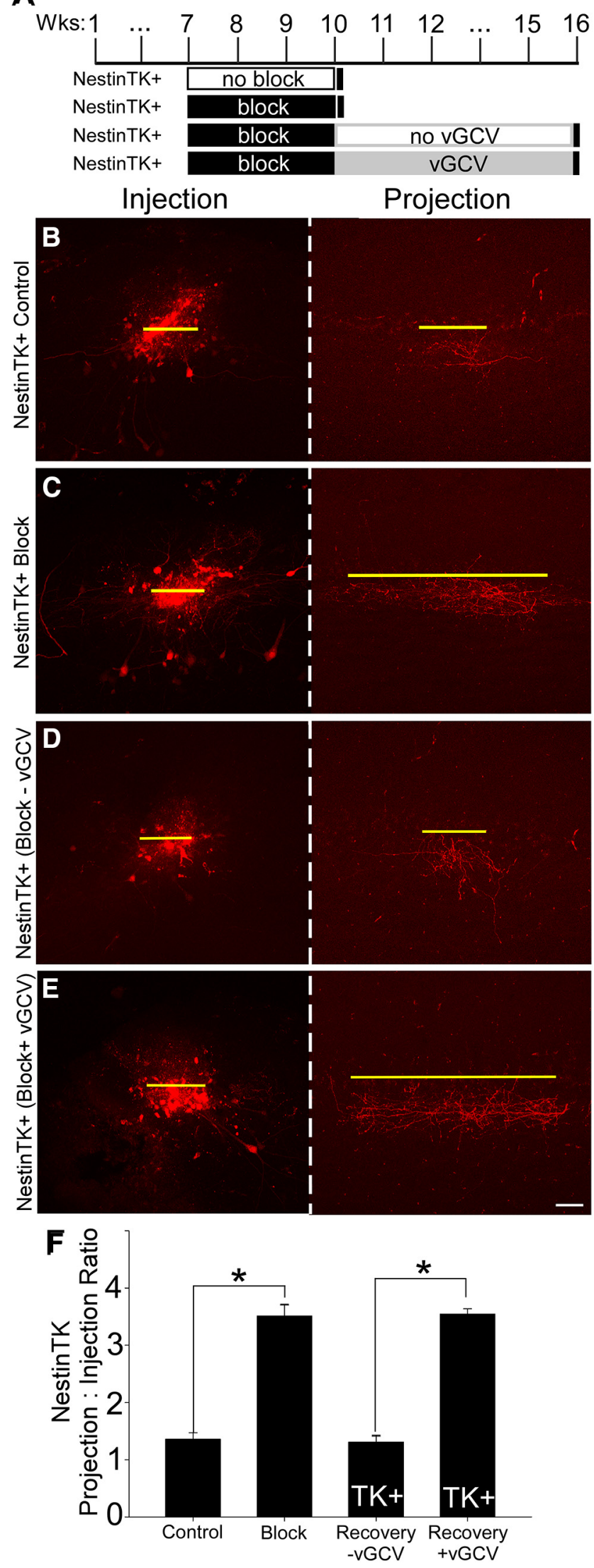

Figure 6. Incomplete ablation of SVZ stem cells also prevents the restoration of intrabulbar projection refinement after sensory block. $\boldsymbol{A}$, Timelines represent groups of NestinTK mice that served as controls or experienced naris closure with or without an incomplete inhibition of seek new postsynaptic partners, and then refine once again as granule cells are replaced.

We also observed a broadening of intrabulbar projections following inhibition of adult neurogenesis in otherwise naive animals, suggesting that the influx of new interneurons is critical for maintaining intrabulbar circuit specificity, even with normal sensory experience and a normal complement of mature granule cells. Interestingly, the GfapTK and NestinTK models exhibited different levels of stem cell ablation. We used two different strains to minimize the chances of nonspecific effects but observed similar results regarding intrabulbar plasticity. Our comparison of the extent of stem cell reduction in GfapTK and NestinTK mice suggests that neural precursors in the RMS are effectively eliminated in both lines; however, stem cell ablation is more complete in GfapTK mice treated with vGCV. Interestingly, the more pervasive ablation of stem cells in GfapTK mice compared with NestinTK mice supports the hypothesis that GFAP-expressing progenitor cells are upstream of Nestin-containing neuroblasts in the SVZ stem cell lineage (Garcia et al., 2004; DeCarolis et al., 2013). The difference in the degree of intrabulbar map expansion was correlated with the extent of stem cell loss, such that the intrabulbar projections of treated $\mathrm{NestinTK}^{+}$mice, which showed incomplete stem cell ablation, were significantly more expanded than those in controls but were not as broad as those in treated $\mathrm{GfapTK}^{+}$mice that experienced total stem cell inhibition. Together, these results suggest that the degree of intrabulbar map refinement can be titrated according to the number of new neurons entering the $\mathrm{OB}$.

Although our data demonstrate that SVZ-derived neuroblasts are critical for the maintenance of the intrabulbar map, blocking the supply of new OB interneurons did not disrupt the targeting of OSN axons to appropriate glomeruli. We examined the convergence of both M71- and P2-expressing glomeruli following stem cell ablation because M71 and P2 odorant receptor neurons have different developmental profiles, and their target glomeruli are located in distinct regions of the $\mathrm{OB}$ (e.g., dorsal vs ventral) (Potter et al., 2001; Zou et al., 2004). Notably, axonal convergence and targeting appeared normal in control mice and in GfapTK $^{+} / \mathrm{M} 71$-taulacZ and GfapTK ${ }^{+} / \mathrm{P} 2$-taulacZ mice that experience stem cell ablation for 6 weeks. The absence of an impact on glomerular convergence indicates that changes in intrabulbar map refinement following stem cell loss are not simply downstream effects emanating from a disrupted glomerular map. The heightened sensitivity of intrabulbar projections to granule cell turnover may stem from the fact that tufted cell axons directly target granule cells (Liu and Shipley, 1994), whereas OSN axons primarily contact mitral and tufted cell dendrites (Kosaka et al., 2001).

In addition to our investigation of new granule neurons and the glomerular map, we examined the effects of the ablation on other neuronal populations in the bulb, including mature granule neurons and the continuously born epithelial neurons. Studies using another mouse model for adult stem cell ablation

neuroblasts from the RMS. As in GfapTK and wild-type mice, intrabulbar projection specificity appeared refined in NestinTK controls $(\boldsymbol{B})$ and broadened in NestinTK mice that underwent naris block from 7 to 10 weeks of age $(\boldsymbol{C})$. When normal levels of neurogenesis occurred after removal of the block, intrabulbar axons appeared refined once again $(\boldsymbol{D})$. However, when adult-born stem cells were largely, but not completely, eliminated in NestinTK ${ }^{+}$mice treated with vGCV after naris block, intrabulbar projections failed to refine to control levels of projection specificity (E). $\boldsymbol{F}$, Graph represents average projection to injection ratios in NestinTK groups. ${ }^{*} p<0.001$. Scale bar, $50 \mu \mathrm{m}$. 
A Wks
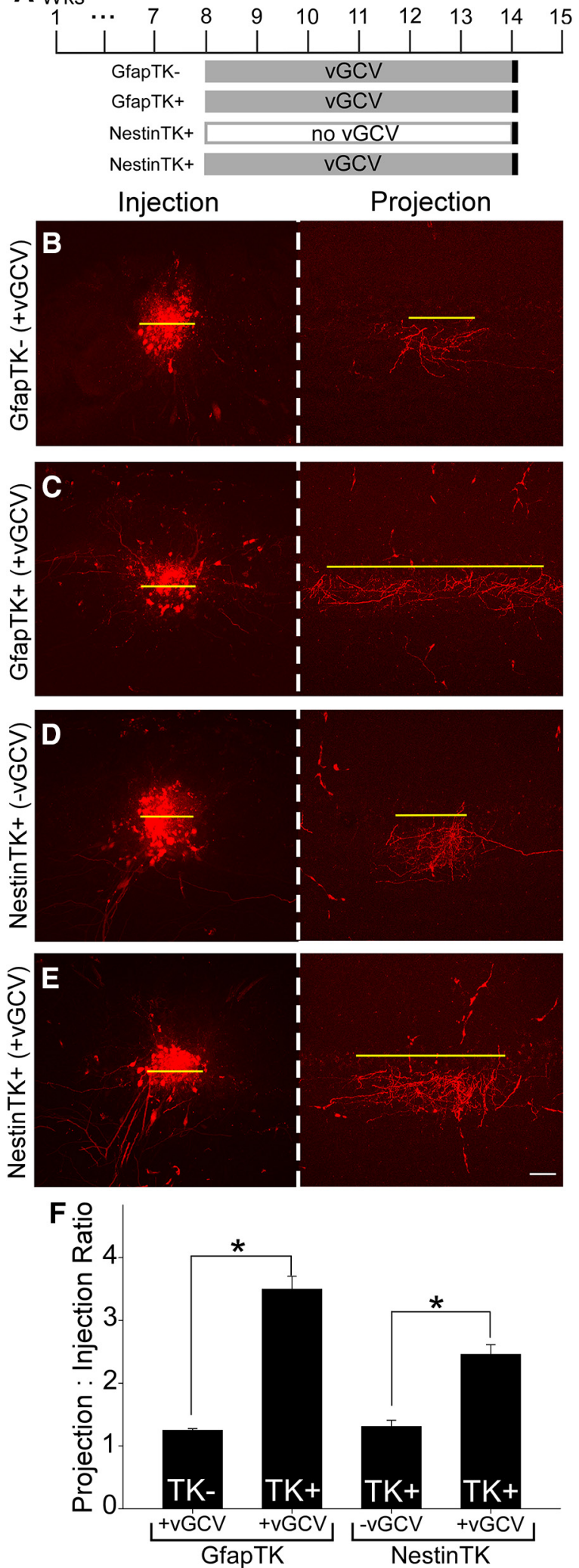

Figure 7. Neurogenesis is required for the maintenance of intrabulbar projection specificity. $\boldsymbol{A}$, Timelines illustrating experimental paradigm: neurogenesis was blocked in naive adult GfapTK and NestinTK mice via vGCV treatment for 6 weeks. Intrabulbar projection specificity was then assessed with discrete tracer injections. $\boldsymbol{B}, \boldsymbol{C}$, Images of representative TMR injection and projection sites (red) show that control mice lacking GfapTK expression had discrete intrabulbar projections, whereas GfapTK ${ }^{+}$mice exhibited broad projection tufts. $\boldsymbol{D}, \boldsymbol{E}$, Intrabulbar projections were also refined in NestinTK mice that were not treated with vGCV to inhibit adult observed gross anatomical abnormalities in the $\mathrm{OB}$ in addition to the absence of new neurons (Imayoshi et al., 2008). Because these structural changes could impact olfactory circuitry independent of the loss of new neurons, we conducted a histological examination of OBs from GfapTK and NestinTK mice treated with vGCV and found no such changes in our models. It is possible that a more severe phenotype is induced in mouse models of stem cell ablation involving diphtheria toxin and tamoxifen treatment compared with thymidine kinase-based models. We also found that proliferation of the olfactory epithelium is unaffected by vGCV treatment in GfapTK and NestinTK lines.

The broadening of intrabulbar projections that occurs in nonoccluded animals when adult-generated neurons are eliminated indicates that preexisting granule cells are not sufficient to maintain intrabulbar map specificity and suggests that long-standing and newly generated granule cells play different roles within the intrabulbar circuit. Indeed, recent work using a genetic approach provides additional support for this theory by demonstrating that granule cells generated during the perinatal period experience less turnover than later-born granule cells and primarily reside in the superficial half of the granule cell layer (Sakamoto et al., 2014). Granule cells are a diverse population, consisting of several chemically defined subpopulations of mature neurons (Imamura et al., 2006; Parrish-Aungst et al., 2007; Batista-Brito et al., 2008; Yoshihara et al., 2012), in addition to the immature subpopulation, which express DCX (Nacher et al., 2001; Brown et al., 2003; Inta et al., 2008). Although beyond the scope of the present study, it would be interesting to determine whether tufted cell axons preferentially target specific subpopulations of granule cells, defined either by cell body location (superficial vs deep) or a molecular identity.

Although a definitive role for adult-born neurons has not been completely elucidated, recent studies have shown that immature neurons exhibit enhanced physiological response profiles compared with preexisting interneurons (Magavi et al., 2005; Nissant et al., 2009). This increased excitability may allow new neurons to transiently compete for limited synaptic space, resulting in a continuous optimization of $\mathrm{OB}$ circuits. Interestingly, this increase in functional plasticity of new neurons also corresponds to a sensitive period when afferent activity is required for their survival, consistent with a competitive integration model (Cummings and Brunjes, 1997; Yamaguchi and Mori, 2005). The present study clearly illustrates the interdependence of the new neurons and the networks that receive them. Our data suggest that, although adult-born neurons require an optimal extracellular milieu to survive, the circuitry that they target also relies on the supply of these new neurons to continuously adjust its organization and maintain stability.

Our results provide the first evidence that adult neurogenesis produces a definitive structural change within a central circuit. To fully understand the unique purpose of adult neurogenesis in neurogenic regions of the brain, it is critical to know how new neurons alter specific circuits to control signal processing as well as how they ultimately affect behavior. The behavioral function of adult neurogenesis in the olfactory bulb is not yet clear, although effects on olfactory learning, social recognition, fear condition-

$\longleftarrow$

neurogenesis, whereas projections of treated NestinTK ${ }^{+}$mice were expanded, as indicated by images of typical injection and projection sites. $F$, Graph represents average projection to injection ratios for GfapTK and NestinTK groups (mean \pm SEM). ${ }^{*} p<0.005$ (one-way ANOVA). Scale bar, $50 \mu \mathrm{m}$. 
ing, odor detection threshold, sex-specific behaviors, and shortterm olfactory memory have all been reported (Mouret et al., 2008; Breton-Provencher et al., 2009; Valley et al., 2009; Mak and Weiss, 2010; Belnoue et al., 2011; Mandairon et al., 2011; Kageyama et al., 2012). Because intrabulbar projections specifically link the medial and lateral $\mathrm{OB}$, it is possible that changes in this circuitry affect the fine-tuning of timing differences that exist between the medial and lateral odor-evoked responses and thus alter the resulting odor code (Zhou and Belluscio, 2012). This in turn could underlie the impairment in many, if not all, of the olfactory-dependent behavioral effects observed in mice lacking adult neurogenesis. Another potential function of continuous circuit reorganization may be to optimize the $\mathrm{OB}$ network in response to changes in olfactory input, thus enabling an effective adaptation mechanism to cope with ever-changing environments. Here we demonstrate a fundamental link between regeneration and circuit plasticity that not only enables the $\mathrm{OB}$ circuitry to restore itself after insult but is also required to maintain anatomical organization under normal conditions.

\section{References}

Batista-Brito R, Close J, Machold R, Fishell G (2008) The distinct temporal origins of olfactory bulb interneuron subtypes. J Neurosci 28:3966-3975. CrossRef Medline

Belluscio L, Lodovichi C, Feinstein P, Mombaerts P, Katz LC (2002) Odorant receptors instruct functional circuitry in the mouse olfactory bulb. Nature 419:296-300. CrossRef Medline

Belluzzi O, Benedusi M, Ackman J, LoTurco JJ (2003) Electrophysiological differentiation of new neurons in the olfactory bulb. J Neurosci 23:1041110418. Medline

Belnoue L, Grosjean N, Abrous DN, Koehl M (2011) A critical time window for the recruitment of bulbar newborn neurons by olfactory discrimination learning. J Neurosci 31:1010-1016. CrossRef Medline

Breton-Provencher V, Lemasson M, Peralta MR 3rd, Saghatelyan A (2009) Interneurons produced in adulthood are required for the normal functioning of the olfactory bulb network and for the execution of selected olfactory behaviors. J Neurosci 29:15245-15257. CrossRef Medline

Brown JP, Couillard-Després S, Cooper-Kuhn CM, Winkler J, Aigner L, Kuhn HG (2003) Transient expression of doublecortin during adult neurogenesis. J Comp Neurol 467:1-10. CrossRef Medline

Carleton A, Petreanu LT, Lansford R, Alvarez-Buylla A, Lledo PM (2003) Becoming a new neuron in the adult olfactory bulb. Nat Neurosci 6:507518. CrossRef Medline

Cummings DM, Belluscio L (2010) Continuous neural plasticity in the olfactory intrabulbar circuitry. J Neurosci 30:9172-9180. CrossRef Medline

Cummings DM, Brunjes PC (1997) The effects of variable periods of functional deprivation on olfactory bulb development in rats. Exp Neurol 148:360-366. CrossRef Medline

Cummings DM, Henning HE, Brunjes PC (1997) Olfactory bulb recovery after early sensory deprivation. J Neurosci 17:7433-7440. Medline

DeCarolis NA, Mechanic M, Petrik D, Carlton A, Ables JL, Malhotra S, Bachoo R, Götz M, Lagace DC, Eisch AJ (2013) In vivo contribution of nestin- and GLAST-lineage cells to adult hippocampal neurogenesis. Hippocampus 23:708-719. CrossRef Medline

Doetsch F, Caillé I, Lim DA, García-Verdugo JM, Alvarez-Buylla A (1999) Subventricular zone astrocytes are neural stem cells in the adult mammalian brain. Cell 97:703-716. CrossRef Medline

Fiske BK, Brunjes PC (2001) Cell death in the developing and sensorydeprived rat olfactory bulb. J Comp Neurol 431:311-319. CrossRef Medline

Garcia AD, Doan NB, Imura T, Bush TG, Sofroniew MV (2004) GFAPexpressing progenitors are the principal source of constitutive neurogenesis in adult mouse forebrain. Nat Neurosci 7:1233-1241. CrossRef Medline

Imamura F, Nagao H, Naritsuka H, Murata Y, Taniguchi H, Mori K (2006) A leucine-rich repeat membrane protein, 5T4, is expressed by a subtype of granule cells with dendritic arbors in specific strata of the mouse olfactory bulb. J Comp Neurol 495:754-768. CrossRef Medline

Imayoshi I, Sakamoto M, Ohtsuka T, Takao K, Miyakawa T, Yamaguchi M,
Mori K, Ikeda T, Itohara S, Kageyama R (2008) Roles of continuous neurogenesis in the structural and functional integrity of the adult forebrain. Nat Neurosci 11:1153-1161. CrossRef Medline

Inta D, Alfonso J, von Engelhardt J, Kreuzberg MM, Meyer AH, van Hooft JA, Monyer H (2008) Neurogenesis and widespread forebrain migration of distinct GABAergic neurons from the postnatal subventricular zone. Proc Natl Acad Sci U S A 105:20994-20999. CrossRef Medline

Kageyama R, Imayoshi I, Sakamoto M (2012) The role of neurogenesis in olfaction-dependent behaviors. Behav Brain Res 227:459-463. CrossRef Medline

Katagiri H, Pallotto M, Nissant A, Murray K, Sassoè-Pognetto M, Lledo PM (2011) Dynamic development of the first synapse impinging on adultborn neurons in the olfactory bulb circuit. Neural Syst Circuits 1:6. CrossRef Medline

Kosaka K, Aika Y, Toida K, Kosaka T (2001) Structure of intraglomerular dendritic tufts of mitral cells and their contacts with olfactory nerve terminals and calbindin-immunoreactive type 2 periglomerular neurons. J Comp Neurol 440:219-235. CrossRef Medline

Lepousez G, Valley MT, Lledo PM (2013) The impact of adult neurogenesis on olfactory bulb circuits and computations. Annu Rev Physiol 75:339363. CrossRef Medline

Liu WL, Shipley MT (1994) Intrabulbar associational system in the rat olfactory bulb comprises cholecystokinin-containing tufted cells that synapse onto the dendrites of GABAergic granule cells. J Comp Neurol 346: 541-558. CrossRef Medline

Lodovichi C, Belluscio L, Katz LC (2003) Functional topography of connections linking mirror-symmetric maps in the mouse olfactory bulb. Neuron 38:265-276. CrossRef Medline

Lois C, Alvarez-Buylla A (1994) Long-distance neuronal migration in the adult mammalian brain. Science 264:1145-1148. CrossRef Medline

Lois C, García-Verdugo JM, Alvarez-Buylla A (1996) Chain migration of neuronal precursors. Science 271:978-981. CrossRef Medline

Magavi SS, Mitchell BD, Szentirmai O, Carter BS, Macklis JD (2005) Adultborn and preexisting olfactory granule neurons undergo distinct experience-dependent modifications of their olfactory responses in vivo. J Neurosci 25:10729-10739. CrossRef Medline

Mak GK, Weiss S (2010) Paternal recognition of adult offspring mediated by newly generated CNS neurons. Nat Neurosci 13:753-758. CrossRef Medline

Mandairon N, Sultan S, Nouvian M, Sacquet J, Didier A (2011) Involvement of newborn neurons in olfactory associative learning? The operant or non-operant component of the task makes all the difference. J Neurosci 31:12455-12460. CrossRef Medline

Marks CA, Cheng K, Cummings DM, Belluscio L (2006) Activitydependent plasticity in the olfactory intrabulbar map. J Neurosci 26 : 11257-11266. CrossRef Medline

Mombaerts P, Wang F, Dulac C, Chao SK, Nemes A, Mendelsohn M, Edmondson J, Axel R (1996) Visualizing an olfactory sensory map. Cell 87:675-686. CrossRef Medline

Mouret A, Gheusi G, Gabellec MM, de Chaumont F, Olivo-Marin JC, Lledo PM (2008) Learning and survival of newly generated neurons: when time matters. J Neurosci 28:11511-11516. CrossRef Medline

Nacher J, Crespo C, McEwen BS (2001) Doublecortin expression in the adult rat telencephalon. Eur J Neurosci 14:629-644. CrossRef Medline

Nissant A, Bardy C, Katagiri H, Murray K, Lledo PM (2009) Adult neurogenesis promotes synaptic plasticity in the olfactory bulb. Nat Neurosci 12:728-730. CrossRef Medline

Panchision DM, Pickel JM, Studer L, Lee SH, Turner PA, Hazel TG, McKay RD (2001) Sequential actions of BMP receptors control neural precursor cell production and fate. Genes Dev 15:2094-2110. CrossRef Medline

Panzanelli P, Bardy C, Nissant A, Pallotto M, Sassoè-Pognetto M, Lledo PM, Fritschy JM (2009) Early synapse formation in developing interneurons of the adult olfactory bulb. J Neurosci 29:15039-15052. CrossRef Medline

Parrish-Aungst S, Shipley MT, Erdelyi F, Szabo G, Puche AC (2007) Quantitative analysis of neuronal diversity in the mouse olfactory bulb. J Comp Neurol 501:825-836. CrossRef Medline

Peretto P, Merighi A, Fasolo A, Bonfanti L (1997) Glial tubes in the rostral migratory stream of the adult rat. Brain Res Bull 42:9-21. CrossRef Medline

Potter SM, Zheng C, Koos DS, Feinstein P, Fraser SE, Mombaerts P (2001) Structure and emergence of specific olfactory glomeruli in the mouse. J Neurosci 21:9713-9723. Medline 
Royal SJ, Key B (1999) Development of P2 olfactory glomeruli in P2internal ribosome entry site-tau-LacZ transgenic mice. J Neurosci 19: 9856-9864. Medline

Sakamoto M, Ieki N, Miyoshi G, Mochimaru D, Miyachi H, Imura T, Yamaguchi M, Fishell G, Mori K, Kageyama R, Imayoshi I (2014) Continuous postnatal neurogenesis contributes to formation of the olfactory bulb neural circuits and flexible olfactory associative learning. J Neurosci 34: 5788-5799. CrossRef Medline

Schoenfeld TA, Marchand JE, Macrides F (1985) Topographic organization of tufted cell axonal projections in the hamster main olfactory bulb: an intrabulbar associational system. J Comp Neurol 235:503-518. CrossRef Medline

Snyder JS, Soumier A, Brewer M, Pickel J, Cameron HA (2011) Adult hippocampal neurogenesis buffers stress responses and depressive behaviour. Nature 476:458-461. CrossRef Medline

Valley MT, Mullen TR, Schultz LC, Sagdullaev BT, Firestein S (2009) Ablation of mouse adult neurogenesis alters olfactory bulb structure and olfactory fear conditioning. Front Neurosci 3:51. CrossRef Medline

Vassalli A, Rothman A, Feinstein P, Zapotocky M, Mombaerts P (2002)
Minigenes impart odorant receptor-specific axon guidance in the olfactory bulb. Neuron 35:681-696. CrossRef Medline

Yamaguchi M, Mori K (2005) Critical period for sensory experiencedependent survival of newly generated granule cells in the adult mouse olfactory bulb. Proc Natl Acad Sci U S A 102:9697-9702. CrossRef Medline

Yoshihara S, Takahashi H, Nishimura N, Naritsuka H, Shirao T, Hirai H, Yoshihara Y, Mori K, Stern PL, Tsuboi A (2012) 5T4 glycoprotein regulates the sensory input-dependent development of a specific subtype of newborn interneurons in the mouse olfactory bulb. J Neurosci 32:22172226. CrossRef Medline

Zhou Z, Belluscio L (2012) Coding odorant concentration through activation timing between the medial and lateral olfactory bulb. Cell Rep 2:1143-1150. CrossRef Medline

Zou DJ, Feinstein P, Rivers AL, Mathews GA, Kim A, Greer CA, Mombaerts P, Firestein S (2004) Postnatal refinement of peripheral olfactory projections. Science 304:1976-1979. CrossRef Medline 